\title{
Analysis on the Training Strategies of University Library Service Talents under the Concept of "Three-all Education" in the New Era
}

\author{
Yingli Lu \\ Shandong Polytechnic, Jinan 250000, Shandong, China \\ Email: 1435538545@qq.com
}

Abstract: Embracing the challenge and mission of the new era, colleges and universities, as an important battle filed for cultivation of talents, should be guided by the educational concept of "Three-all Education", to train and transport outstanding talents for the country. Based on the concept of "Three-all Education" and centering on the innovative ability of college library service personnel training, this paper utilizes big data technology and means to realize the idea of "all-process education, all-staff education and all-round education", and explores the cultivation strategies for college library service personnel, which not only meets the urgent needs of college reform and development. It is also of great practical significance to cultivate young talents in the new era.

Keywords: Three-all Education, university library, talent training

\section{Introduction}

President Xi Jinping put forward that ideological and political work should run through the whole process of education and teaching, and realize the innovative mode of talents training in colleges and universities, which is"all-process education, all-staff education and all-round education". As an important organization for universities in cultural development, university library is an important embodiment of university culture connotation. The main function of library is to provide education and information services, which is also of great significance in supporting scientific research, promoting academic spirit and inheriting campus culture. From the perspective of cultivation of service personnel of university library, this paper firstly introduces the connotation of the concept of "Three-all Education" in the new era. Secondly, it analyzes the application of big data in university library. Finally, the paper puts forward the cultivation path of service talents of university library under the concept of "three integrity education".

\section{The connotation of the concept of Three-all Education}

According to the CPC Central Committee and The State Council's Opinions on Strengthening and Improving Ideological and Political Work in Colleges and Universities under the New Situation, the party insists on the concept of "all-process education, all-staff education and all-round education". Colleges and universities should integrate education in ideology and morality, culture and social practice into the education and teaching work, forming a series of long-term and all-round education mechanism. The concept of "Three-all Education" is also a multi-disciplinary educational concept, which advocates the education of cultivating the comprehensive quality of moral education necessary for the development of college students' career. Colleges and universities should provide necessary services for talent cultivation through multichannels and internal multi-department cooperation. How to implement personnel training service in university Library?This paper mainly expounds from two aspects of big data and library service methods.

\section{The era of big data and libraries}

University library is an institution that records, stores, disseminates and applies humanities and data. The tasks of data processing are growing in an exponential manner, especially with the proliferation of social media, mobile smart terminals and wireless networks, and the massive growth of structured and semi-structured data. The library has ushered in the era of development of big data. In the era of big data based wisdom, people continue to explore the integration of big data wisdom and digital library.

In the era of big data, the university library is confronted with the problem of acquisition and utilization in data resource. Users' information literacy is getting higher and higher, and their demand for library service is getting higher and higher, which puts forward more stringent requirements for the quantity and quality of information. At this time, university libraries need to change service mode and improve service quality to satisfy users. The library can exploit the potential data value 
through the user's historical data and search information, so as to provide personalized service for users, and finally improve the service quality. University libraries should provide personalized service for students. The characteristics of personalized service are mainly reflected in the following aspects: high-level personalized service; Knowledge based service is endowed with characteristics of wide -range coverage of disciplines with a large span and a high degree of professionalism. The demand for resources is personalized with strong will and swift changes in demand. In the process of knowledge discovery, users are highly interacted with knowledge service system. As a result, users can use knowledge resources and also produce knowledge resources.

\section{Research on library service methods}

University libraries store all kinds of knowledge and wisdom in the form of documents, electronic resources and network information. Well-equipped libraries are documentation centers, knowledge service centers, self-study centers and social and cultural centers. In light of knowledge innovation, market information potential analysis, resource consulting and data mining services, university libraries should integrate the concept of "Three-all Education" in the new era by making use of abundant library resources, transforming the service mode in an all-round and multi-channel way, and actively investigating the trend of students' needs, so as to make plans and provide information for students in a targeted way, creating a rich cultural atmosphere. Colleges and universities can also strengthen cooperation with local autonomous groups to make college students understand morality based education policies. Through big data, information about moral education can be obtained from the Internet and media, and ideological and moral education and guidance can be carried out for students. Multi-departments in the university should conduct cooperation to provide all-round services for talent cultivation in colleges and universities. The specific measures are as follows.

\subsection{Set up literature retrieval courses for smooth acquisition of resources for students}

Enrich collection resources and improve the quality of resources. Whether a university library is qualified can be judged from the following aspects. (1) Whether it enjoys rich collection resources. (2) Whether the proportion of discipline resources is reasonable. (3) Whether the quality of resources is in high level. (4) Whether the utilization rate of information resources is in high level. At present, both national and local governments have certain threshold requirements for the available resources per capita in university libraries. Under the circumstance of increasing collection, university library still faces some problems such as insufficiency of available digital resources, shortage of latest resources, unreasonable allocation of subject resources and low utilization rate of information resources. A rich collection of resources can help learners increase their knowledge reserves. Moreover, innovation in a single discipline is rarely and difficult to achieve. Each university has comparative advantages in disciplines that are easier to attract library data and resources. In this case, library managers should take reasonable measures to allocate disciplinary resources. The library should introduce the latest paper resources, establish digital resources, provide convenience for teachers and students to improve their knowledge and ability, and make efficient and reasonable use of the rich collection resources. Literature retrieval can be used to obtain useful resources in the following ways.

First of all, the ability to access data resources quickly and efficiently is one of the abilities that innovative library service personnel should have. Chinese university students are not proficient in information collection and utilization, which, if improved, will lay a solid foundation for future entrepreneurs and researchers. Therefore, information retrieval education is one of the important tasks in the educational link of university library, which can cultivate readers' knowledge consciousness and ability to acquire and use literature information. Libraries can also take influential social or academic issues as the theme, adopt practical forms such as debate and discussion so as to teach students how to check and collect information, identify and screen original information, judge the quality of information, and to make a second or even third analysis and utilization of literature. As a result, students' ability of information acquisition, screening, identification, integration and utilization can be cultivated and improved.

Secondly, college teachers or librarians should set up literature retrieval courses for college students, so that students can get access to information retrieval, the current situation of their own major and the cutting-edge knowledge of various disciplines in the courses, so as to better play the role of professional services. The content of literature retrieval course should be easy for understanding and practical operation. In general, task-driven teaching method is adopted to study cooperatively and exploratively the utilization status of library resources and improve students' information retrieval ability. For example, the course "Scientific and Technological Writing and Literature Retrieval" combines ideological and moral education with professional teaching, such as haruko Obokata's "Universal cell" paper fraud in Japan, so that students can understand the serious consequences of academic misconduct and cultivate students' good academic moral habits.

Third, university librarians carry out different levels of education for different users: (1) library index for freshmen; 
(2) Literature lectures and information skills training were held for all teachers and students. Literature retrieval courses of libraries has been open in Shandong normal university for nearly 20 years, with contents involving the electronic library and network resources. Thirdly, information literacy training will be conducted for undergraduates and postgraduates in batches and at different levels to introduce the retrieval theory and application skills of literature resources in the era of all media to students, so as to improve their academic writing standards and information literacy.

\subsection{Strengthen cooperation between schools and departments and providing personalized services for students}

The fundamental countermeasure to cope with the function fragmentation in the new era is to establish the dominant position of library in many functional departments. By integrating the independent data resources of previous functional departments, a multi-functional department collaboration mechanism is constructed to overcome the fragmentation problem and improve the overall function and efficiency. These include personnel departments, science and technology departments, libraries, and admissions and employment departments. Depending on processing data resources, libraries can use semantic analysis, semantic association, and clustering algorithms to bring useful data into local repositories. Effectively realize data fusion, generate new data information for users to use, after the fusion of data resources can not only improve the utilization rate, but also convenient for students to use.

Second, to strengthen the data resources of colleges and universities and data aggregation among library departments, and analysis of big data mining and exploitation and decision system of university library can be built based on all kinds of data collection, extraction, cleaning, correlation and analysis of all academic institutes as well as the potential value of the data, which provides a solid analysis and decision driving model for the development of university library, and provides decision and management analysis foundation for university and library managers.

In the new era, university libraries should cultivate elite personnel who are well developed morally, intellectually, physically and aesthetically. Through collection resources and data analysis, students can be given targeted moral education to help them grow up healthily. This educational concept should be rooted in students' minds, rather than just a formality.

(1) Actively guide students to correctly learn from the experience and lessons of previous moral educators from the library collection to cultivate students' down-to-earth attitude.

(2) Provide students, especially senior students, with successful experience and cases based on big data technology, and to arrange case learning for improvement of students' comprehensive ability.

(3) Invite successful practitioners in moral education to share their stories with students, including difficulties, efforts and comprehensive quality education experienced in moral education practice. To help establish students good ideological and moral confidence so as to lay a solid foundation in the future.

(4) Actively provide simulation environment and practice platform for college students' concept of all-round education in the new era. Students can receive ideological and moral education imperceptibly in practice.

\section{Conclusion}

University library is the hub of human knowledge and wisdom, and library should make full use of its own resources and play a leading role in the new era. By integrating the data resources of various functional departments of colleges and universities, the library obtains high-quality information from the data resources of various departments and provides intelligent service for the cultivation of talents in colleges and universities. Under the guidance of the concept of "Three-all Education" in the new era and based on the combination of moral education for students, students will establish a correct outlook on life and values, which aims to cultivate talents to meet the needs of the development of the society.

\section{References}

[1] Qin Yurong. The concept of "Three-all Education" is implemented throughout the education and teachingprocess[EB/ OL]. http://www.zgxymyw.cn/html/meiyuxinwen/201810/29-3081.html, 2018-10-29/2021-10-07.

[2] Li Yonghong. The status and role of university library in university[J]. Technology and Business. 2015(11): 166.

[3] Tie Feng, Huang Changwei. Research on the role and service path of university library in undergraduate talent training[J]. Inner Mongolia Science technology \& Economy, 2021(11): 125-128.

[4] Central People's Government of People's Republic of China. The CPC Central Committee and The State Council issued opinions on Strengthening and Improving Ideological and Political Work in Universities under the New Situation [Z]. 2021-10-08 
[5] Wang Ruixia. Strategies for strengthening the training of reading promotion service talents in university libraries[J]. Inside and Outside Lantai, 2021(17): 61-63.

[6] Yurutuzi Tohetasen. Research on collaborative teaching service model of university library based on innovative talent training[J]. Chinese \& Foreign Corporate Culture, 2021(05): 22-23.

[7] Li Xiaohong. Research on university Library service based on "Entrepreneurship and Innovation" talent cultivation[J]. Office Operation, 2021(05): 165-166.

[8] Ma Yue. Construction of Collaborative Education Service System of University Library for first-class talent cultivation[J]. The Library Journal of Henan, 201, 41(02): 58-61.

[9] Liu Jing, Han Ruiping, Zhang Yuan, Cui Lanhua. Research on collaborative teaching service model and evaluation system of university library for innovative talents training[J]. Information Research, 2020(12): 97-102.

[10] The CPC Central Committee and The State Council issued opinions on Strengthening and Improving Ideological and Political Work in Colleges and Universities under the New Situation. xinhuanet.com. 